\title{
Strengths and Weaknesses of Using Tablets in Rural University Classrooms: A South African Perspective
}

\author{
Simon Christopher Fernandez ${ }^{1, *}$, Kuttickattu John Mammen ${ }^{2}$ \\ ${ }^{1}$ Faculty of Science, Engineering and Technology, Walter Sisulu University, South Africa \\ ${ }^{2}$ School of General \& Continuing Education, University of Fort Hare, South Africa
}

Received May 15, 2020; Revised June 24, 2020; Accepted July 20, 2020

\section{Cite This Paper in the following Citation Styles}

(a): [1] Simon Christopher Fernandez, Kuttickattu John Mammen, "Strengths and Weaknesses of Using Tablets in a Rural University Classrooms: A South African Perspective," Universal Journal of Educational Research, Vol. 8, No. 9, pp. 3937 - 3945, 2020. DOI: 10.13189/ujer.2020.080918.

(b): Simon Christopher Fernandez, Kuttickattu John Mammen (2020). Strengths and Weaknesses of Using Tablets in a Rural University Classrooms: A South African Perspective. Universal Journal of Educational Research, 8(9), 3937 3945. DOI: 10.13189/ujer.2020.080918.

Copyright $\mathrm{C} 2020$ by authors, all rights reserved. Authors agree that this article remains permanently open access under the terms of the Creative Commons Attribution License 4.0 International License

\begin{abstract}
Technologies especially tablets are rapidly booming up daily around the world and it reflects in all areas including education. The purpose of this study was to examine the views of stakeholders such as students, lecturers and managers on the strengths and weaknesses of using tablets for learning and teaching at a South African rural university. This research adopted a mixed method study. Although interview data were collected from all stakeholders, survey data were collected only from lecturers. A total of 14 lecturers from a relevant population of 25 voluntarily participated in the survey. However, only 18 students, five lecturers and nine managers were interviewed. Quantitative data were captured manually into Statistical Package for Social Sciences (version 24). While quantitative data were analysed using descriptive statistics, qualitative data were analysed using thematic analysis. The study found the strengths such as gathering information and researching as well as weaknesses such as distractions and social networking during lecture hours. Generally, strengths were greater than the weaknesses and all stakeholders were positive on the use of tablets for learning and teaching in classroom. However, the researchers suggest that training and awareness presentations should be provided to both lecturers and students at the beginning of each academic year to make the use of tablet in classroom more effective.
\end{abstract}

Keywords Tablet Computers, Educational Technology, Mobile Technology, Rural University Education

\section{Introduction}

Nowadays, institutions play a significant role in building good citizens by providing excellent education to students through new Information and Communication Technologies (Keating, 2013). Mobile technologies are increasingly being used to support blended learning beyond computer centres (Mayisela, 2013). Mobile technologies such as mobile phones and tablets can highly supplement students' interest in studies and produce effective academic results when blended with traditional strategy. These technologies enable the students to perform mobile learning by being online and work more independently inside and outside the classroom (Menkhoff \& Bengtsson, 2012). Amongst all the mobile devices, tablet has created a positive impact in all fields particularly in education (Cochrane, Narayan, \& OldField, 2013). Tablets in institutions encourage innovative teaching methods such as game-based learning (Chen, 2012), exploratory learning outside the classroom (Liu, Lin, Tsai, \& Paas, 2012) and cooperative learning (Lan, Sung, \& Chang, 2007) by gathering and sharing the information. The method of technology based teaching is spreading all over the world particularly in universities (Castillo-Manzano, Castro-Nuño, López-Valpuesta, Sanz-Díaz, \& Yñiguez, 2017; Henderson, Selwyn, \& Aston, 2017). 
In Barone's and Wright's (2009) view, tablet has helped students to interact and communicate with their classmates and educators very easily due to its ability to share and pass information. A study conducted in Midwestern state college reported positively on the cognitive skill, organization and learning motivation of students using tablets in classroom and at home (Dyer, 2013). Based on the findings of a study conducted by Oblinger (2003) on the use of internet by adolescents, $41 \%$ of them used emails and instant messages to communicate with their teachers for the purpose of learning. Tablet apps provide significant benefits to the educators especially to design and prepare study materials and curriculum which make it easier for them to devise instructional strategies (Ludwig \& Mayrberger, 2012).

Mobile technologies that create benefits in higher education can also create drawbacks (Kim, Mims, \& Holmes, 2006). Kinash, Brand, and Mathew (2012) record the off-task behaviour of students using tablets during lecture time which includes checking mail, web browsing and visiting social networking sites such as Facebook and Twitter. Research conducted by Mifsud (2002) has shown that educators cannot determine the students' activities while they are using tablets in classroom. Vuorikari, Garoia, and Balanskat (2011) undermine the position that tablet computers make the work harder for an educator as it is a convenient tool for students to access internet very easily during any situation. A study conducted in Stanford University and University of Notre Dame revealed that management and students were unhappy with the use of tablets and discontinued it within a few weeks' time (Fischman \& Keller, 2011).

\subsection{Problem Statement}

It is unmistakable from the above literature that many institutions ubiquitously are using tablets for learning and teaching. However, there is a lack of research on how the use of tablets affects the learning style of students (Wakefield, Frawley, Tyler, \& Dyson, 2018). Furthermore, despite tablets are considered as the most modern tool which is used in the field of education (Cochrane et al., 2013), little published studies have been done in South Africa to confirm that tablets are useful for classroom instruction (Shuler, 2012; Rafiki, 2015). Many higher education institutions in South Africa are planning to adapt tablet technology without having sufficient knowledge whether it could provide intended purposes. Therefore, gathering and examining the views of relevant stakeholders such as students, lecturers and managers on the strengths and weaknesses of tablet use in learning and teaching is a worthy problem for investigation.

\subsection{Literature Review}

A case study was conducted in one of the universities in Indiana State to examine students' impressions of mobile technology, particularly tablets in the classroom. The results showed that tablets provided a collaborative learning environment that included debates, developing knowledge, discussing ideas together, participating in classroom activities and thereby having a greater interaction between each other (Rossing, Miller, Cecil, \& Stamper, 2012). Likewise, findings of the tablet study conducted at Pepperdine University by Weider (2011) revealed that tablets enhanced the collaboration between student and lecturer in terms of sharing tablet screen images while solving Calculus problems in Mathematics.

A pilot study was conducted at Loyola Marymount University, USA with 30 faculty participants to examine potential pedagogical uses of $t$ tablet. The researchers Yeung and Chung (2011) discussed the benefits and challenges of using tablet as well. This study is one of the first tablet Exploration Projects (iPEP) that is cross disciplined and collaborative enough to encourage the faculty to check the effectiveness of using tablet in educational sector. Qualitative analysis was performed to code all the data in a software called Nvivo 9. The faculty responded that tablet was very useful in terms of accessing the library resources and course resources very quickly. Tablet also helped the lecturers to communicate with students instantly. Some of the challenges they have confronted were related to apps where either preferred apps were not available or it was too expensive to purchase.

Additionally, a research done by Pegrum, Howitt, and Striepe (2013) investigated the existing academic uses of handheld devices in tertiary institutions and the views of pre-service teachers in tablet use on their learning about teaching. Semi structured interview, non-participant observation and focus group interview were the three types of data collection methods used for the study. Eight pre-service teachers in the faculty of education at the University of Western Australia participated in the study. The findings reported that tablet use facilitated them to study a new way of learning and enhanced their understanding of the pedagogy, content and helped to stay connected and organized.

In recent times, a large study was conducted in seven vocational college campuses to investigate the perception of both faculty and students on the productivity of using tablet in classrooms. About 51 faculties from various programs such as criminal justice, dental hygiene, medical billing and coding, medical assisting, pharmacy technology and dental assisting participated in the survey. The population of the faculties from all the campuses of the various programs were 130 . As the design was mixed-method, both quantitative and qualitative methods had been used to collect the data. Findings of this study showed that the perception of faculties and students were not identical. While faculties indicated that their experience of using tablet in classroom was challenging, students believed that tablets had helped them to have a high engagement in the classroom. However, the 
qualitative result showed that both faculties and students believed tablets caused distraction in learning environment (Reed, 2017).

A qualitative study was conducted by Bennett (2014) in a small Midwestern town to determine the perceptions of administrators and directors to evaluate the effectiveness of tablet integration into curriculum and instruction. Three administrators and two directors from the Department of Technology and Curriculum were interviewed to collect the data. All the respondents unanimously believed that there was a high level of pertinence and prominence of integrating technologies including iPad tablets into the classroom for the purpose of instruction and students learning. Additionally, not only integrating technologies into education sector but also offering trainings to students and academics on how to use it effectively was also essential.

\subsection{Purpose of the Study}

The purpose of this study was to examine the views of stakeholders such as students, lecturers and managers on the strengths and weaknesses of using tablets for learning and teaching at a rural university in Eastern Cape Province of South Africa. Therefore, this study was guided by the research question: Based on stakeholders' views, what are the strengths and weaknesses of using tablets for learning and teaching?

\section{Materials and Methods}

\subsection{Research Approach and Design}

The study was anchored on mixed-method approach as it permits to collect in-depth information through quantitative and qualitative method. This approach also enables to present additional complementary data on the research topic. Case study was the research design used along with the elements of survey and interview.

\subsection{Study Site}

The study was conducted in one of the four campuses of a rural university in the Eastern Cape province of South Africa. The main justification for choosing this rural university as the study site was due to the fact that this was the only university in this area where tablets were provided for the purpose of education.

\subsection{Population and Sample}

The sample consisted of 14 lecturers from a population of 25 lecturers in Information and Communication Technology (ICT) and Electrical Engineering (EE) voluntarily participated in the survey. A total of 18 Extended-Stream (ES) National Diploma students from the ICT and EE cohorts, five lecturers from the ICT and EE cohorts and nine managers (one Dean, three Heads of different Departments, one e-learning specialist, one e-learning administrator, two extended programme coordinators and one Institutional Head of Extended programme coordinator) were interviewed. As EE department was in the same building of ICT, it was convenient for the main researcher to collect the data from all stakeholders. Although interview data were collected from students, lecturers and managers, survey data were collected only from lecturers. The main researcher collected the data from all participants at the end of 2017.

After conducting interviews with all stakeholders, there was a strike going on in the campus which prolonged for many days. As the exams commenced immediately after the strike, all stakeholders were busy with their works and they were not willing to participate in the survey. However, later lecturers accepted to participate in the survey with a condition that questionnaire must be emailed to them. As the main researcher was an academic of the study site, he was already having the email addresses of the lecturers. These reasons made the researchers in taking the decision to include only the lecturers in the survey.

ES was one of the divisions of National diploma programmes in this University with inadequate knowledge in understanding their diploma programmes. Main Stream (MS) was another division of diploma programme. The university had purchased tablets in bulk from the fund that was allocated for ES to enhance their studies and it was first distributed to all ES lecturers and ES students in 2014 and thereafter distributed every year. All ES lecturers and ES students were using tablets for their educational purposes. As the tablets were provided only to ES students, this study does not include MS students.

\subsection{Data Collection Instruments}

While interview was conducted to collect the data from all stakeholders, survey was conducted to collect the data only from lecturers. The researchers made a 5-point Likert-scale questionnaire comprised of two sections to collect the survey data from lecturers. Demographic data were collected from the first section and the main data were collected from the second section. There were totally five levels in the scale in which first level (1) denotes strongly disagree, second level (2) denotes disagree, third level (3) denotes no opinion, fourth level (4) denotes agree and fifth level (5) denotes strongly agree. The researchers used multiple sources to develop the questionnaire. As the use of tablets in school and higher education institutions is similar, the researchers had a detailed study on the literature of both types of institution which assisted in drawing up the questionnaires. Three questionnaire items that was used by Agir (2015) had been modified to use in this study. Cronbach Alpha value was used to determine the reliability of lecturers and the result was 0.700. Furthermore, the researchers had created interview protocols for all stakeholder cohorts. A total of five key interview questions were used to collect the data from students. While the 
researchers used six key interview questions to collect the data from lecturers, only five key interview questions were used to collect the data from managers.

\subsection{Ethical Compliances and Pilot Study}

The researchers had followed all ethical compliances to corroborate the study but not compromising the faith the participants had on them. The main researcher conducted a pilot study with five lecturers prior to the commencement of the main study. The participants who were part of the pilot study were not involved in the main study. The main researcher had done an interview rehearsal with three students, three lecturers and three managers before the actual interview which helped the main researcher to be accurate and consistent when the actual data were collected.

\subsection{Data Collection Procedures}

The main researcher officially met each and every lecturer and explained the research, the purpose of the questionnaire although all the details were described in the questionnaire. The questionnaire was sent to the lecturers in the sample and collected back from all of them through email and hence their response rate was $100 \%$. As the main researcher was an academic of the research site, he arranged his office itself to interview the students, lecturers and a few managers such as Deans and Heads of different departments. All other managers were interviewed in their office spaces considering their convenience. Responses collected through interview from students, lecturers and managers were recorded using professional audio recording software installed in main researcher's laptop and high quality smart phones.

\subsection{Data Analysis}

The responses collected using survey were captured by the researchers into Statistical Package for Social Sciences (Version 24) and they were analysed using descriptive statistics. The thematic approach was used with qualitative data to analyse and triangulate to confirm the findings. The responses collected using interview were transcribed and analysed. The researchers generated major theme and sub-themes from the responses of the participants to understand the in-depth knowledge on the strengths and weaknesses of using tablets for learning and teaching in university classroom.

\section{Results}

\subsection{Quantitative Findings}

It was observed that $79 \%$ of the lecturers agreed and $7 \%$ of them strongly agreed that students started to read eBooks after getting tablets (item B1). Around 14\% of the lecturers were uncertain.

Additionally, item B2 revealed that $36 \%$ of the lecturers agreed and $29 \%$ of them strongly agreed that students used tablets to gather information. About $14 \%$ of the lecturers disagreed on item B2 and $21 \%$ of them did not have any opinion.

Around $57 \%$ of the lecturers agreed and $7 \%$ of them strongly agreed that students started communicating with lecturers (item B3). While $29 \%$ of the lecturers disagreed on item B3, 7\% of them were uncertain.

It can be seen that $50 \%$ of the lecturers agreed and $7 \%$ of them strongly agreed that students used tablets to e-learn through Blackboard or Wiseup (item B4). Around 7\% of the lecturers strongly disagreed on item B4 and $36 \%$ of them were indeterminate.

It was observed that $57.1 \%$ of the lecturers agreed and $14.3 \%$ of them strongly agreed that they did research after getting tablets (item B5). About $14.3 \%$ of the lecturers disagreed and another $14.3 \%$ were uncertain.

While $29 \%$ of the lecturers agreed and $7 \%$ of them strongly agreed that students started to learn multiple learning styles using tablets (item B6), 57\% did not have any opinion and $7 \%$ disagreed.

Around $43 \%$ of the lecturers agreed and $29 \%$ of them strongly agreed that students took photos of the lecture highlights on white board (item B7). About $14 \%$ of the lecturers disagreed and another $14 \%$ were uncertain.

When $54 \%$ of the lecturers agreed and $15 \%$ of them strongly agreed that students submitted their work to the lecturer through email or file sharing apps (item B8), 23\% disagreed, $8 \%$ were indeterminate and one student did not answer.

Furthermore, about $31 \%$ of the lecturers agreed and $15 \%$ of them strongly agreed that students started to use tablet during lecture for taking notes (item B9). Around $15 \%$ of the lecturers disagreed on item B9, 39\% preferred a neutral stance and one student did not answer. 
Table 1. Lecturers' views in the survey about the strengths and weaknesses of using tablets

\begin{tabular}{|c|c|c|c|c|c|c|c|}
\hline \# & ITEM & SD & D & NO & $\mathbf{A}$ & SA & $\mathbf{N}$ \\
\hline B1 & After getting tablet, students started to read e-books. & $\begin{array}{c}0 \\
(0 \%)\end{array}$ & $\begin{array}{c}0 \\
(0 \%) \\
\end{array}$ & $\begin{array}{c}2 \\
(14 \%) \\
\end{array}$ & $\begin{array}{c}11 \\
(79 \%)\end{array}$ & $\begin{array}{c}1 \\
(7 \%) \\
\end{array}$ & $\begin{array}{c}14 \\
(100 \%)\end{array}$ \\
\hline B2 & After getting tablet, students started to gather information & $\begin{array}{c}0 \\
(0 \%)\end{array}$ & $\begin{array}{c}2 \\
(14 \%)\end{array}$ & $\begin{array}{c}3 \\
(21 \%)\end{array}$ & $\begin{array}{c}5 \\
(36 \%)\end{array}$ & $\begin{array}{c}4 \\
(29 \%)\end{array}$ & $\begin{array}{c}14 \\
(100 \%)\end{array}$ \\
\hline B3 & $\begin{array}{c}\text { After getting tablet, students started communicating with } \\
\text { me. }\end{array}$ & $\begin{array}{c}0 \\
(0 \%)\end{array}$ & $\begin{array}{c}4 \\
(29 \%)\end{array}$ & $\begin{array}{c}1 \\
(7 \%)\end{array}$ & $\begin{array}{c}8 \\
(57 \%)\end{array}$ & $\begin{array}{c}1 \\
(7 \%)\end{array}$ & $\begin{array}{c}14 \\
(100 \%)\end{array}$ \\
\hline B4 & $\begin{array}{l}\text { After getting tablet, students started e-learning through } \\
\text { Black Board. }\end{array}$ & $\begin{array}{c}1 \\
(7 \%)\end{array}$ & $\begin{array}{c}0 \\
(0 \%)\end{array}$ & $\begin{array}{c}5 \\
(36 \%)\end{array}$ & $\begin{array}{c}7 \\
(50 \%) \\
\end{array}$ & $\begin{array}{c}1 \\
(7 \%)\end{array}$ & $\begin{array}{c}14 \\
(100 \%)\end{array}$ \\
\hline B5 & After getting tablet, students started doing research. & $\begin{array}{c}0 \\
(0 \%)\end{array}$ & $\begin{array}{c}2 \\
(14.3 \%) \\
(14 \%)\end{array}$ & $\begin{array}{c}2 \\
(14.3 \%) \\
\end{array}$ & $\begin{array}{c}8 \\
(57.1 \%) \\
\end{array}$ & $\begin{array}{c}2 \\
(14.3 \%) \\
\end{array}$ & $\begin{array}{c}14 \\
(100 \%)\end{array}$ \\
\hline B6 & $\begin{array}{c}\text { After getting tablet, students started to learn multiple } \\
\text { learning styles. }\end{array}$ & $\begin{array}{c}0 \\
(0 \%)\end{array}$ & $\begin{array}{c}1 \\
(7 \%)\end{array}$ & $\begin{array}{c}8 \\
8 \\
(57 \%)\end{array}$ & $\begin{array}{c}4 \\
(29 \%)\end{array}$ & $\begin{array}{c}1 \\
(7 \%)\end{array}$ & $\begin{array}{c}14 \\
(100 \%)\end{array}$ \\
\hline B7 & $\begin{array}{l}\text { After getting tablet, students started to take photos of the } \\
\text { lecture highlights on white board to avoid copying by } \\
\text { hand. }\end{array}$ & $\begin{array}{c}0 \\
(0 \%)\end{array}$ & $\begin{array}{c}2 \\
(14 \%)\end{array}$ & $\begin{array}{c}2 \\
(14 \%)\end{array}$ & $\begin{array}{c}6 \\
(43 \%)\end{array}$ & $\begin{array}{c}4 \\
(29 \%)\end{array}$ & $\begin{array}{c}14 \\
(100 \%)\end{array}$ \\
\hline B8 & $\begin{array}{l}\text { After getting tablet, students started to submit their work } \\
\text { to the lecturer through email or a file sharing apps. }\end{array}$ & $\begin{array}{c}0 \\
(0 \%)\end{array}$ & $\begin{array}{c}3 \\
(23 \%)\end{array}$ & $\begin{array}{c}1 \\
(8 \%)\end{array}$ & $\begin{array}{c}7 \\
(54 \%)\end{array}$ & $\begin{array}{c}2 \\
(15 \%)\end{array}$ & $\begin{array}{c}13 \\
(100 \%)\end{array}$ \\
\hline B9 & $\begin{array}{l}\text { After getting tablet, students started to use tablet during } \\
\text { the lecture for taking notes. }\end{array}$ & $\begin{array}{c}0 \\
(0 \%)\end{array}$ & $\begin{array}{c}2 \\
(15 \%)\end{array}$ & $\begin{array}{c}5 \\
(39 \%) \\
\end{array}$ & $\begin{array}{c}4 \\
(31 \%)\end{array}$ & $\begin{array}{c}2 \\
(15 \%)\end{array}$ & $\begin{array}{c}13 \\
(100 \%)\end{array}$ \\
\hline
\end{tabular}

Note. $\#=$ item number, $\mathrm{SD}=$ Strongly Disagree, $\mathrm{D}=$ Disagree, $\mathrm{NO}=$ No opinion, $\mathrm{A}=$ Agree, $\mathrm{SA}=$ Strongly Agree and $\mathrm{N}=$ Total Answered.

\subsection{Qualitative Findings}

Following are the key interview questions used to collect the data from all stakeholder cohorts:

\subsubsection{Students}

1. Do you use tablets for any activities other than learning during lecture hours? If yes, what are they?

2. Do you use tablets for any activities other than learning after the class hours? If yes, what are they?

3. What benefits have you obtained from your use of tablet computers as a learning tool?

4. What drawbacks have you noticed in your use of tablet computers as a learning tool?

5. Would you like to share anything else with me about your use of tablets in classroom?

\subsubsection{Lecturers}

1. What benefits have you obtained from your use of tablet computers as a teaching tool?

2. What drawbacks have you noticed in your use of tablet computers as a teaching tool?

3. What are the different tablet activities that are not related to learning which you have noticed very often among students while you lecture in classroom?

4. What benefits have you noticed for students in their use of tablet computers as a learning tool?

5. What drawbacks have you noticed for students in their use of tablet computers as a learning tool?

6. Would you like to share anything else with me about the students use and your use of tablets in classroom?

\subsubsection{Managers}

1. What benefits have you noticed for students in their use of tablet computers as a learning tool?

2. What benefits have you noticed for lecturers in their use of tablet computers as a teaching tool?

3. What drawbacks have you noticed for students in their use of tablet computers as a learning tool?
4. What drawbacks have you noticed for lecturers in their use of tablet computers as a teaching tool?

5. Would you like to share anything else with me about the student use and lecturers' use of tablets?

The researchers had used aliases in order to refer to the stakeholders who have participated in the interview. Accordingly, students, lecturers and managers were labeled as StuInter, LectInter and ManInter respectively along with the numbers. The major theme that was generated after the collection of data was strengths and weaknesses of tablet use. The five sub themes that had emerged from the major theme after the triangulation by sources are student's non-learning activities in class, benefits as a learning tool, drawbacks as a learning tool, benefits as a teaching tool and drawbacks as a teaching tool.

On the aspect of the first sub-theme, "students' non-learning activities in class", responses received from $80 \%$ of the students were that they did not use it for activities that were not part of learning during class hours. StuInter 5: "I don't use it for those kinds of any activities". StuInter 6: "No. I do use the tablets only for learning activities like searching for the topics". On the other hand, three respondents have concurred that they used for non-learning activities. StuInter 12, StuInter 16 and StuInter 17 used tablets to chat with friends through social networking sites such as Facebook, Twitter and Whatsapp. Lecturers' point of view on students accessing social media during lecture time was a common issue that all respondents highlighted. LectInter 1 stressed that students were very tricky as they could switch very fast between Facebook and eBook in tablets during the class hours. LectInter 2: "They are very addicted to using the tablets to do something that is not related to learning even when the lecture goes on".

On the aspect of the second sub-theme, "benefits as a learning tool", all the students mentioned that it was highly beneficial for them as a learning tool. StuInter 1: "It has 
enhanced my learning capability and I also got easy access to my school work on Wiseup, then I can browse on the internet to browse more details". The response of StuInter 7 and StuInter 13 corroborated with the response of StuInter 1. Majority of the lecturers indicated that students had different kinds of benefits in using tablet as a learning tool. LectInter 1: "Yes. In terms of accessing the information... in terms of Engagement with the lecturer. Yes there is an improvement". LectInter 2 remarked that tablets delivered to students was a great help and benefit for them as each student had a tablet and they could be used just like they do on their computer such as going to google and gather information. LectInter 3: "There are benefits. They do online chats, they create brainstorming sessions through the tablet". All the managers corroborated with most of the lecturers. Students changed the way they had been learning after the implementation of tablet use. ManInter 9 suggested that tablets motivated students to aim for high marks, helped to communicate with each other in sharing notes and this made them to read notes quickly. ManInter 1 stated that it was more convenient for the students to learn their courses by being from anywhere.

On the aspect of the third sub-theme, "drawbacks as a learning tool", majority of the students agreed that tablets had a few drawbacks. StuInter 5 raised the concern that WI-FI connections in the university premises were very poor and speed was low which did not help to use tablets effectively as it had only WI-FI facility and did not have SIM card facility. The responses of StuInter7 and StuInter 10 were substantiated with the response of StuInter 5. StuInter 1, StuInter 2 and StuInter 9 did not find any drawbacks except that some applications were not compatible with the tablets. For example, some of the programming courses such as $\mathrm{C}++$ or code blocks failed to be installed on all tablets. Majority of the lecturers agreed that tablets had caused some drawbacks among students. LectInter 3: "If the network is down they cannot download anything". LectInter 2 averred that the normal activities of students have come down due to the continuous use of tablet. Instead of doing even the regular exercise of walking, they are always sitting down and spending their valuable time on tablets. LectInter 4 stated that drawbacks are the disruption that the tablets have brought into their learning although it has many benefits for learning. Majority of the managers agreed that there were some drawbacks. ManInter 3 affirmed that the only drawback is that students abuse the tablet by doing non-educational activities. ManInter 9 stated that one of the drawbacks was that students can very easily access all social networking sites. ManInter 4 corroborated with the views of ManInter 3 and ManInter 9. However, ManInter 5 and ManInter 7 declared that they did not notice any drawbacks in the tablet use of students.

On the aspect of the fourth sub-theme, "benefits as a teaching tool", most of the lecturers obtained several benefits from the use of tablet as a teaching tool. LectInter
2 stated that tablets were very useful in terms of uploading the assignments for students and they could also explore by searching the internet using tablet. LectInter 3 obtained benefit in the case of sending notes to students through Wiseup. LectInter 5: "The same thing whatever I am doing or whatever I am using in laptops all those benefits I was getting even in the tablets". In managers' point of view, Lecturers had a positive attitude in terms of using tablets for teaching and they benefitted from the use of tablets. ManInter 6: "it is easy to change the material as it is in the electronic format". ManInter 2 averred that "It makes environment the class environment conducive to learning and teaching because the information is at their fingertip". ManInter 8 stressed that overall he could find only positive things about the use of tablets and it was an effective tool for teaching.

On the aspect of the fifth sub-theme, "drawbacks as a teaching tool", majority of the lecturers had pointed out some drawbacks that they suffered while using tablet as a teaching tool. LectInter 2 highlighted the plagiarism issues that arose due to the use of tablets in classroom. When LectInter 2 posted some assignment questions in Wiseup for students to do, they just copied and pasted the answer they found from the internet without using their competitive skills. LectInter 3: "Students cannot rely on Wi-Fi. They cannot access any email if they're outside the campus. They don't have the SIM card provision, their tablets have only Wi-Fi facility". However, one respondent mentioned that he did not see any drawbacks. Most of the managers did not see any drawbacks in tablets as a teaching tool. ManInter 6: "No I'm not aware of any that kind of thing". ManInter 3: "Not really significant other than the tablets are working very well for the teaching and learning". ManInter 1, ManInter 5 and ManInter 7 also substantiated the views of earlier respondents.

\section{Discussion}

Findings obtained from lecturers through survey and interview itself contradicted on students' non-learning activities in class. While the survey results showed that students used tablets for the purpose of learning such as taking notes during lectures, interview results revealed that students were involved more with social media than the lecture. On the other hand, responses received from $80 \%$ of the students were that they did not use it for non-learning activities during class hours which is inconsistent with the findings by Mang and Wardley (2013) who indicate that checking personnel emails and social networking in class declined students from focusing on the lecture. The researchers of the current study observed that these off-task behaviours could be due to some students who do not know the positive side of using tablets for learning. This attitude may change once they understand the multiple ways of learning using tablets. This will also help them to have 
interest in the subjects. Moreover, although taking notes is a part of learning, the researchers observed that using tablet for taking notes disadvantages the students' handwriting and pace when they write the examinations.

Findings from survey and interview were consistent in showing that tablets have many benefits as a learning tool. All the stakeholders had a common opinion that tablet was a learning tool that offered plenty of benefits such as reading e-Books, gathering information, communicating with lecturers, e-learning through Black Board, researching, taking photos of the lecture highlights on white board and submitting works to the lecturer through email or file sharing apps. Findings of the current study are consistent with the views of Mang and Wardley (2013) as they aver that majority of the students believed that tablet is an innovative tool for learning. The main attractive part of tablet is that it is a light-weight tool that can be taken anywhere for learning purposes.

Interview findings collected from all stakeholders were consistent in showing that tablets have some drawbacks as a learning tool. Findings of the current study are therefore in line with the findings by Reed (2017) that in his study, both faculties and students unanimously agreed that tablets caused distraction in learning environment. The researchers of the current study observed that despite having many benefits, tablets also have some drawbacks. This can be solved if the management of the institution can provide an awareness program to the students to make them understand the dos and don'ts of tablet use for an active learning.

Findings from the interviews showed that both lecturers and managers were consistent and observed that tablets offered numerous benefits as a teaching tool. Chou, Block, and Jesness (2012) found that after academics started using iPad tablets, they spent more time in assisting students in project work and less time to lecture. Consequently, the result of the current study is consistent with the findings by Chou et al. (2012). Tablets convert lecturers to facilitators as this gadget has the power to change teacher-centered learning to student-centered learning which is in line with the views of the current study lecturers.

As no device is perfect, so were tablets. Findings from the interviews showed that lecturers and managers were inconsistent in showing that tablets have drawbacks as a teaching tool. Most of the lecturers indicated the drawbacks of tablets as a teaching tool from their experiences in the classroom. Conversely, most of the managers did not see any drawbacks in tablets as a teaching tool. However, Chou et al.'s (2012) results are similar to the responses of lecturers that there are drawbacks. Gadgets have benefits as well as drawbacks and the results of the current study endorse that. It could be mainly because of some students who are causing distraction during lecture hours. Moreover, there are limitations for a lecturer to monitor each and every student in what activity they are engaged with tablet while lecturing.

\section{Conclusions, Limitation, Recommendations and Implications}

Like any other technology, tablet computers also have strengths as well as weaknesses. In this study, the researchers found that tablets had more strengths than weaknesses. After the adoption of tablets, now students could engage in learning activities with little dependence on lecturers. Gathering information, downloading and reading eBooks, researching, taking photos of the lecture highlights on white board and submitting works through email or a file sharing apps made the device more attractive for students. Students used tablets by understanding the benefits of the technology. Although there were some drawbacks for tablet as a teaching tool, lecturers had a positive attitude in terms of using tablets for teaching as they have benefited its user-friendliness and in making the class environment conducive for learning and teaching. Additionally, students and managers were also positive on the use of tablets for the purpose of education in classroom.

Sample size of lecturers used in the survey can be considered as a limitation. The researcher made the following recommendations to the management or institution that are planning to implement tablets in their classrooms:

(a) Purchase tablets that have both Wi-Fi facility and SIM card facility in order for the students and lecturers to use tablets even when the internet connection is poor.

(b) Wi-Fi routers with good strength should be fixed at strategic places campus-wide including campus residences in order for the students to access internet at any time.

(c) Lecturer must explain the Do's and Don'ts on the first day itself to all the students. Lecturers must also have a clear understanding on how to use the tablets in the classroom.

(d) On-site training and awareness presentations should be provided to both lecturers and students at the beginning of each academic year to make the use of tablet in the classroom more effective.

Finally, in regard to implications, the results of this study can trigger further research on the comparison of students' use of tablets in universities with the learners' use of tablets in schools. These results are substantial to managers, curriculum planners, lecturers and teachers in designing and developing the learning materials to incorporate tablets in education for an active student-centred learning. Management and the officials of higher education institutions and schools need to insist that stakeholders need to use tablet for learning and teaching only. 


\section{REFERENCES}

[1] Agir, A. (2015). iPad at School: A Holistic Evaluation of the Opinions of Students, Teachers and Parents Concerning iPad Use. International Journal of Education, 7(3), 175-193. doi:10.5296/ije.v7i3.7924.

[2] Alyahya, S., \& Gall, J. E. (2012). tablets in education: A qualitative study of students' attitudes and experiences. In: T. Amiel and B. Wilson, (Eds).Proceedings of World Conference on Educational Multimedia, Hypermedia and Telecommunications (pp. 1266-1271). Chesapeake, Virginia.

[3] Barone, D., \& Wright, T.E. (2009). Literacy instruction with digital and media technologies. The Reading Teacher, 62(4), 292-302. https://doi.org/10.1598/RT.62.4.2.

[4] Bennett, J. E. (2014). A case study of the integration of technology and instruction in a rural midwestern school district. Ph.D. University of Missouri.

[5] Castillo-Manzano, J. I., Castro-Nuño, M., López-Valpuesta, L., Sanz-Díaz, M. T., \& Yñiguez, R. (2017). To take or not to take the laptop or tablet to classes, that is the question. Elsevier,68,326-333.https://doi.org/10.1016/j.chb.2016.11.0 17

[6] Chen, H.R. (2012). Design of Mobile Learning-Recommendation Services Supporting Small-Screen Display Interfaces. In: A. Xie and X. Huang, eds. Advances in Computer Science and Education. Advances in Intelligent and Soft Computing. Springer, Berlin, Heidelberg.

[7] Chou, C.C., Block, L., \& Jesness, R. (2012). A case study of mobile learning pilot project in K-12 schools. Journal of Educational Technology Development and Exchange, 5(2), 11-26. http://files.eric.ed.gov/fulltext/ ED557233.pdf.

[8] Cochrane, T., Narayan, V., \& OldField, J. (2013). tabletagogy: Appropriating the tablet within pedagogical contexts. International Journal of Mobile Learning and Organisation, 7(1), 48-65. doi:10.1504/IJMLO.2013.051573.

[9] Dyer, C. (2013). Examining College Students' Perceptions of tablet Use on Motivation, Organization, and Cognitive Skills. Master of Education (MEd). Bowling Green State University.

[10] Fischman, J., \& Keller, J. (2011, August 21). College Tech Goes Mobile. Chronicle of Higher Education. Retrieved from http://www.chronicle.com/article/College-Tech-GoesMobile/128614/

[11] Geist, E. (2011). The Game Changer: Using tablets in College Teacher Education Classes. College student journal, 45(4), 758-768.

[12] Hahn, J., \& Bussell, H. (2012). Curricular use of the tablet 2 by a first-year undergraduate learning community. In: R. K. Miller, C. Meier and H. Moorefield-Lang, eds. Library Technology Reports (pp. 42-47).

[13] Henderson, M., Selwyn, N., \& Aston, R. (2017). What works and why? Student perceptions of 'useful' digital technology in university teaching and learning. Studies in Higher Education, 42(8), 1567-1579. https://doi.org/10.1080/03075079.2015.1007946.

[14] Keating, A. (2013). Educating tomorrow's citizens: what role can schools play?. In: Keynote Lecture at the Annual School Leadership Conference for Head teachers in Slovenia, Organised by the Ministry of Education and National School for Leadership in Education. Slovenia.

[15] Kim, S. H., Mims, C., \& Holmes, K. P. (2006). An introduction to current trends and benefits of mobile wireless technology use in higher education. Association for the Advancement of Computing in Education, 14(1), 77-100. https://pdfs.

semanticscholar.org/6e76/f5ee5deb2fc4078cb8b040ed7df9 cccdf83f.pdf

[16] Kinash, S., Brand, J., \& Mathew, T. (2012). Challenging mobile learning discourse through research: Student perceptions of Blackboard Mobile Learn and tablets. Australasian Journal of Educational Technology, 28(4), 639-655. doi: 0.14742/ajet.832.

[17] Lan, Y. J., Sung, Y. T., \& Chang, K. E. (2007). A mobile-device-supported peer-assisted learning system for collaborative early EFL reading. Language Learning \& Technology, 11 (3), 130-151. https://www.learntechlib.org/ $\mathrm{p} / 74464 /$.

[18] Liu, T. C., Lin, Y. C., Tsai, M. J., \& Paas, F. (2012). Split-attention and redundancy effects in mobile learning in physical environments. Computers \& Education, 56(2), 172-180. http://dx.doi.org/10.1016/j.compedu.2011.08.007.

[19] Ludwig, L., \& Mayrberger, K. (2012). Next generation learning? Learning with tablets as an example for the implementation digital media in schools. In: T. Amiel and B. Wilson, eds. Proceedings of the World Conference on Educational Multimedia, Hypermedia and Telecommunications (pp. 2179-2187). Denver, CO.

[20] Mang, C. F., \& Wardley, L. J. (2013). Student perceptions of using tablet technology in post-secondary classes. Canadian Journal of Learning and Technology, 39(4), 1-16. doi: $10.21432 / \mathrm{T} 22010$.

[21] Mayisela, T. (2013). The potential use of mobile technology: enhancing accessibility and communication in a blended learning course. South African Journal of Education, 33(1), 1-18. doi: 10.15700/saje.v33n1a629.

[22] McBeth, M. K., Turley-Ames, K., Youngs, Y., Ahola-Young, L., \& Brumfield, A. (2015). The iPad Pilot Project: A Faculty Driven Effort to Use Mobile Technology in the Reinvention of the Liberal Arts. Journal of Teaching and Learning with Technology, 4(1), 1-21. https://doi.org/10.14742/ajet.187

[23] Menkhoff, T., \& Bengtsson, M. (2012). Engaging Students in Higher Education Through Mobile Learning: Lessons Learnt in a Chinese Entrepreneurship Course. Educational Research for Policy and Practice, 11, 225-242. https://doi.org/10.1007/s10671-011-9123-8.

[24] Mifsud, L. (2002). Alternative Learning Arenas Pedagogical Challenges to Mobile Learning Technology in Education. IEEE International Workshop on Wireless and Mobile Technologies in Education. 
[25] Oblinger, D. (2003). Boomers \& gen-xers millennials understanding the new students. EDUCAUSE, 38(4), 36-47.

[26] Pegrum, M., Howitt, C., \& Striepe, M. (2013). Learning to take the tablet: How pre-service teachers use tablets to facilitate their learning. Australasian Journal of Educational Technology, 29(4), 464-479. doi: 10.14742/ajet.187.

[27] Rafiki, M. (2015). Pedagogical integration of the ipad to enhance teaching and learning of grade 10 life sciences. Masters of education. University of the Witwatersrand.

[28] Reed, A. R. (2017). Perceptions on the effectiveness of tablet integration in vocational college classrooms: a mixed-methods study. Ph.D. Northwest Nazarene University.

[29] Rossing, P. J., Miller, W. M., Cecil, A. K., \& Stamper, S. E. (2012). iLearning: The future of higher education? Student perceptions on learning with mobile tablets. Journal of the Scholarship of Teaching and Learning, 12(2), 1-26. https://files.eric.ed.gov/.

[30] Shen, Y. W. (2016). An evaluation of the impact of using tablets in teacher education. The Online Journal of New
Horizons in Education, 6(4), 18-25. https://www.tojned.net/

[31] Shuler, C. (2012, January). iLearn II. An Analysis of the Education Category of the iTunes App Store. Retrieved from http://www.joanganzcooneycenter.org/wp-content/uploads/ 2012/01/ ilearnii.pdf.

[32] Vuorikari, R., Garoia, V., \& Balanskat, A. (2011). Introducing Netbook Pedagogies in Schools. Acer European School net Educational Netbook Pilot. Brussels: European Schoolnet.

[33] Wakefield J., Frawley J.K., Tyler J., \& Dyson L.E. (2018). The impact of an iPad supported annotation and sharing technology on university students' learning. Computers \& Education, 122, 243-259. https://doi.org/10.1016/j.compedu. 2018.03.013.

[34] Weider, B. (2011, March 13). Tablets could hinder teaching, professors say. Chronicle of Higher Education. Retrieved fromhttp://chronicle.com/article/tablets-for-College-Classro oms-/126681/

[35] Yeung, M., \& Chung, H. (2011). iPEP talk: pedagogical conversations from the iPad Exploration Project. 